\title{
Growth, Yield, and Sugar Content of Different Varieties of Sweet Corn and Harvest Time
}

\author{
St. Subaedah (D), Edy Edy ${ }^{D}$, and Kiky Mariana $(\mathbb{D}$ \\ Department of Agrotechnology, Universitas Muslim Indonesia, Urip Sumoharjo Road 226, Makassar 90231, Indonesia \\ Correspondence should be addressed to St. Subaedah; st.subaedah@umi.ac.id
}

Received 17 June 2020; Revised 2 December 2020; Accepted 26 December 2020; Published 7 January 2021

Academic Editor: David Clay

Copyright (C) 2021 St. Subaedah et al. This is an open access article distributed under the Creative Commons Attribution License, which permits unrestricted use, distribution, and reproduction in any medium, provided the original work is properly cited.

\begin{abstract}
The demand for sweet corn has increased largely because of its superior tastes compared with common corn. This research was conducted to analyze the growth and yield and sugar content of sweet corn seed on different varieties and harvest times. This research was conducted in South Sulawesi, Indonesia, from April to August 2018. The research was designed under a split-plot design. The main plot consisted of planting systems (single row and twin-row), whereas subplots consisted of three varieties (Bonanza, Talenta, and Master Sweet) and three harvest times (65, 70, and 75 days after planting). Variables measured consisted of plant height, cob length, cob weight, estimation of cob weight per hectare, and sugar content. Significant varietal differences were observed in plant height, cob length, cob weight, and sugar content. Master Sweet variety had the greatest plant height and cob length, whereas Bonanza variety produced the greatest cob weight, cob weight per hectare, and sugar content. Harvest time at 75 days after planting (DAP) produced the greatest plant height in the twin-row system, cob diameter, cob weight, and cob weight per hectare, whereas that at $65 \mathrm{DAP}$ had the greatest plant height in control and sugar content. The twin-row system produced the greatest cob weight per hectare $(22.33$ ton/ha). This study recommends the use of Bonanza variety and harvest at $65 \mathrm{DAP}$ to produce the greatest sweet corn cob per hectare.
\end{abstract}

\section{Introduction}

Sweet corn is a variety of corn with high sugar content and has a high nutritional value $[1,2]$. In Indonesia, sweet corn was first known in the form of imported cans. In the 1980s, this corn variety was cultivated in Indonesia commercially on a small scale [3]. Furthermore, sweet corn is increasingly known and widely consumed; therefore, the demand for sweet corn has been increasing. Sweet corn production in Indonesia remained low with average production below 10 tons/hectares (Wibowo, 2017). This situation led to an increase in imports from 1,010,178 tons in 2011 to $1,125,463$ tons in 2014 . Hence, developing superior, highyielding sweet corn varieties through plant breeding is necessary. Cultivation technologies such as enhancing cropping systems and selecting proper varieties are among efforts to increase domestic production. The potential of land for developing sweet corn cultivation in Indonesia is huge; however, in fact, the production was only reached
8.31 tons/ha or only one-third of the potential possessed [4].

The low sweet corn production in Indonesia is due to the development of sweet corn generally in the marginal dry land, whereas dry land is confronted with many issues such as limited water availability and low soil fertility $[5,6]$. Therefore, sweet corn production should be increased, for instance, by enhancing appropriate cultivation technology [7]. An essential factor in enhancing cultivation technology is spacing and the selection of varieties. The selection of sweet corn varieties is a key process for increasing production [8].

Sweet corn has varying sugar levels. Local varieties have a sugar content of $9 \%-11 \%$, whereas hybrid sweet corn varieties have a sugar content of $16 \%-18 \%$ [9]. The sweet corn quality is determined by the presence of sugar content of sweet corn kernels [10]. The sugar content of sweet corn is influenced by varieties and by harvest time [11]. The prompt harvest maturity is necessary to ensure quality corn 
sweetness [12]. Previous research has been conducted on relatively fertile land with organic systems [13]. Research conducted on marginal land with the application of the Legowo planting system has never been done. This research is designed to increase crop productivity through increasing plant populations by adjusting the spacing and to utilize the effects of edge plants, in which planting is done by reducing the distance of the plant in a row and widening the range between the plants. The Legowo system is the twin-row system with wider space in between. It has a denser space within rows and a wider one between the twins to foster the yield. However, the application of the Legowo system to corn still shows inconsistent results compared with conventional systems. The present study aims to analyze the growth, yield, and sweet corn seed sugar content of various varieties and harvest times with the application of the Legowo spacing system.

\section{Materials and Methods}

This research was conducted in Gowa Regency, South Sulawesi Province, Indonesia, from April to August 2018. The climate characteristic in the study site was classified as C2 (according to Oldman's classification), monthly rainfall ranges from $0-560 \mathrm{~mm}$, with an altitude of $10 \mathrm{~m}$ above sea level. Soil type was alluvial with moderate $\mathrm{pH}$ and $C$-organic content, while the nitrogen content was low (Table 1).

Three varieties of sweet corn (Bonanza, Talenta, and Master Sweet) were used in the present study as these hybrid varieties had high yield potential (Surtinah, 2015; Abadi and Sugiharto, 2019).

This study adopted a split-split plot design, which consists of the two main plots, three subplots, and three subsub plots (Figure 1). The main plot consisted of planting treatments as follows:

$P 0=$ control (single row planting system with a spacing of $70 \mathrm{~cm} \times 25 \mathrm{~cm}$ )

$P 1=$ treatment (Legowo planting system or twin-row with a spacing of $50 \mathrm{~cm} \times 25 \mathrm{~cm}$ and between twins of $100 \mathrm{~cm}$ )

The subplots consisted of varieties:

$$
\begin{aligned}
& V 1=\text { Bonanza variety } \\
& V 2=\text { Talenta variety } \\
& V 3=\text { Master Sweet variety }
\end{aligned}
$$

While sub-sub plots consisted of

$$
\begin{aligned}
& H 1=\text { harvested at } 65 \mathrm{DAP} \\
& H 2=\text { harvested at } 70 \mathrm{DAP} \\
& \mathrm{H} 3=\text { harvested at } 75 \mathrm{DAP}
\end{aligned}
$$

Of the three factors, 18 combinations of treatments were obtained. Each combination of treatments was replicated three times to obtain 54 units, sampling from sub-subplots.

Land preparation was done by hoeing the soil and cleaning the weeds and roots. The land was divided into two blocks: control and treatment. Each block was split into
TABLE 1: Summary of soil characteristics.

\begin{tabular}{lcc}
\hline Soil characteristics & Values & Criteria \\
\hline $\mathrm{pH}$ & 5.9 & Acid \\
$\mathrm{C}$ (Walkey \& Black) & $2.14 \%$ & Moderate \\
$\mathrm{N}$ (Kjeldahl) & $0.11 \%$ & Low \\
$\mathrm{C} / \mathrm{N}$ & 19 & High \\
$\mathrm{P}_{2} \mathrm{O}_{5}$ (Olsen) & $10.6 \mathrm{ppm}$ & Low \\
$\mathrm{K}$ & $0.11 \mathrm{cmol} / \mathrm{kg}$ & Low \\
$\mathrm{KTK}$ & $21.65 \mathrm{cmol} / \mathrm{kg}$ & Moderate \\
$\mathrm{K}_{2} \mathrm{O}$ & $22.65 \mathrm{mg} / 100 \mathrm{~g}$ & Moderate \\
\hline
\end{tabular}

three subplots each represented varieties, while a subsubplot represented different harvest times. Corn seeds of all varieties were planted in the subplots randomly. Thinning was done at $14 \mathrm{DAP}$, leaving one plant for each hole and 9 plants in each sub-subplots. Fertilizers consisted of $350 \mathrm{~kg} / \mathrm{ha}$ of urea, $150 \mathrm{~kg} / \mathrm{ha}$ of phosphate, and $150 \mathrm{~kg} / \mathrm{ha}$ of potassium chloride were applied for all the treatments. Application of two-thirds of urea, phosphate, and potassium chloride was done a week after planting, while onethird application of urea was done a month after planting. Watering was performed manually every week during the plant growth phase. Weeds were controlled by applying the herbicide on 21 and 40 DAP. Harvesting was done by sampling three plants in each subplot at the age of 65,70 , and 75 DAP. The variables observed were plant height, cob length, cob diameter, cob weight, cob weight per hectare, and seed sugar content observed in the form of total dissolved solids. Measurement of plant heights for all treatments was conducted at 56 DAP, while the length, diameter, and weight of cobs were measured directly at harvest time. Cob lengths and diameter were measured by a caliper. Cob weight was measured using a digital balance. The cob weight per hectare was extrapolated by multiplying cob weight with the corn population per hectare $(56800$ stalks/ha in control and 60000 stalks/ha in treatment). The sugar contents of harvested corns were measured using Refractometer. The corn beans were squeezed out, and the corn liquid was put onto the glass prism of the refractometer. The result was seen through the eyepiece. The data obtained were calculated using analysis of variance followed by the least significant difference (LSD) multiple range test $(p<0.05)$ using SPSS 20.

\section{Results and Discussion}

3.1. Effect of Spacing System, Sweet Corn Variety, and Harvest Time on Different Plant Growth and Yield Parameters. Planting system $(P)$ significantly affected cob weight per hectare, variety $(V)$ significantly affected all variables except cob diameter, and harvest time $(H)$ significantly affected all variables except cob length. The interaction between spacing the system and variety did not affect any variable. The interaction between the planting system and harvest time significantly affected the cob weight and cob weight per hectare. Interaction between variety and harvest time $(V * H)$ as well as interaction among all factors $(P * V * H)$ did not significantly affect all variables (Table 2 ). 


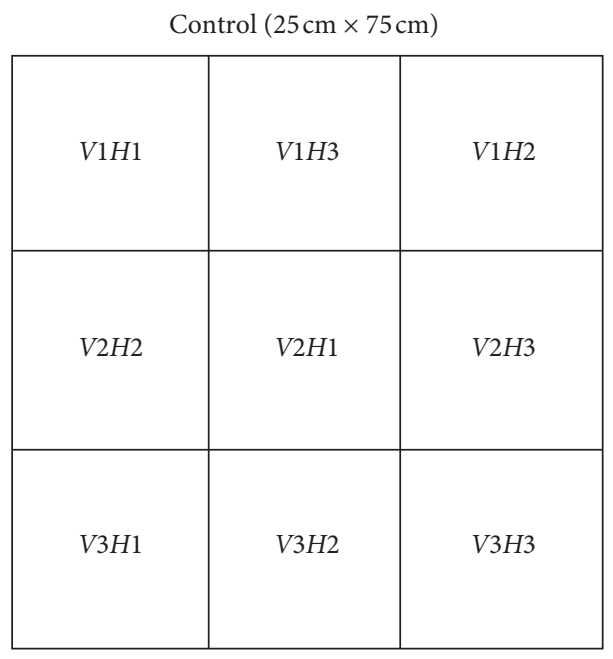

$\begin{aligned} V 1 & =\text { bonanza } \\ V 2 & =\text { talenta } \\ V 3 & =\text { master sweet }\end{aligned}$
$H 1=$ harvested at $65 \mathrm{DAP}$

$H 2=$ harvested at $70 \mathrm{DAP}$

$\mathrm{H} 3=$ harvested at $75 \mathrm{DAP}$

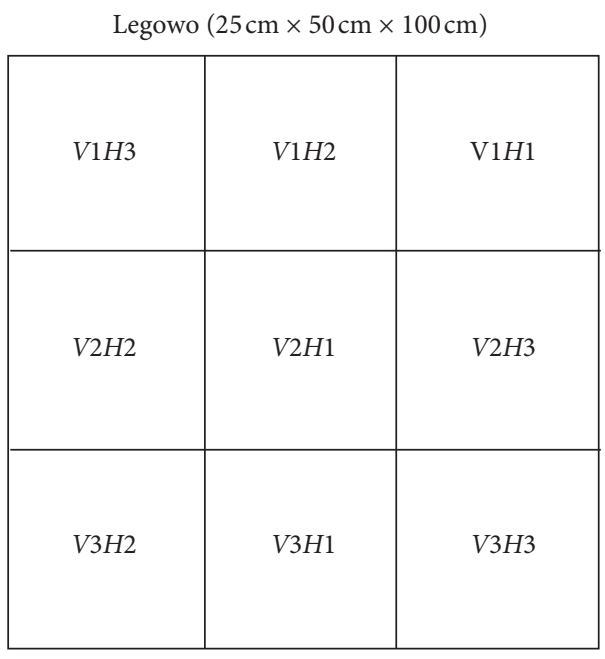

$V 1$ = bonanza

$H 1=$ harvested at $65 \mathrm{DAP}$

$\mathrm{H} 2=$ harvested at $70 \mathrm{DAP}$

$H 3=$ harvested at $75 \mathrm{DAP}$

FIGURE 1: Experimental field treatment by adopting a split-split plot design.

TABLE 2: Summary of F statistic followed by the probability of the effect of the spacing system, variety, and harvest time on growth, yield, and sugar content of sweet corn.

\begin{tabular}{|c|c|c|c|c|c|c|c|}
\hline Parameter & $\begin{array}{c}\text { Planting } \\
\text { system }(P)\end{array}$ & $\begin{array}{l}\text { Variety } \\
(V)\end{array}$ & $\begin{array}{l}\text { Harvest } \\
\text { time }(H)\end{array}$ & $\begin{array}{l}\text { Interaction } \\
\quad(P * V)\end{array}$ & $\begin{array}{l}\text { Interaction } \\
\quad(P * H)\end{array}$ & $\begin{array}{l}\text { Interaction } \\
\quad(V * H)\end{array}$ & Interaction $(L * V * H)$ \\
\hline Plant height & $6.81^{\mathrm{ns}}$ & $52.02^{* *}$ & $5.46^{* *}$ & $1.23^{\mathrm{ns}}$ & $0.25^{\mathrm{ns}}$ & $2.48^{\text {ns }}$ & $1.92^{\mathrm{ns}}$ \\
\hline Cob length & $0.00^{\text {ns }}$ & $8.47^{*}$ & $3.23^{\mathrm{ns}}$ & $0.83^{\text {ns }}$ & $0.13^{\mathrm{ns}}$ & $1.50^{\mathrm{ns}}$ & $0.09^{\mathrm{ns}}$ \\
\hline Cob diameter & $1.43^{\mathrm{ns}}$ & $2.73^{\text {ns }}$ & $7.56^{* *}$ & $0.06^{\mathrm{ns}}$ & $1.96^{\mathrm{ns}}$ & $1.97^{\mathrm{ns}}$ & $0.22^{\mathrm{ns}}$ \\
\hline Cob weight & $2.26^{\mathrm{ns}}$ & $11.71^{* *}$ & $20.18^{* *}$ & $0.18^{\mathrm{ns}}$ & $7.13^{* *}$ & $2.33^{\mathrm{ns}}$ & $0.55^{\mathrm{ns}}$ \\
\hline $\begin{array}{l}\text { Cob weight per } \\
\text { hectare }\end{array}$ & $32.17^{*}$ & $11.13^{* *}$ & $19.36^{* *}$ & $0.08^{\mathrm{ns}}$ & $6.45^{* *}$ & $2.33^{\mathrm{ns}}$ & $0.57^{\mathrm{ns}}$ \\
\hline $\begin{array}{l}\text { Seed sugar } \\
\text { content }\end{array}$ & $1.48^{\mathrm{ns}}$ & $5.33^{*}$ & $10.81^{* *}$ & $0.19^{\mathrm{ns}}$ & $0.09^{\mathrm{ns}}$ & $1.71^{\mathrm{ns}}$ & $0.47^{\mathrm{ns}}$ \\
\hline
\end{tabular}

Note. Significance ${ }^{*} p<0.05,{ }^{* *} p<0.01$, ns $=$ not significant.

3.2. Plant Height. The results of the analysis of plant height on various varieties and harvest times showed that the variety had a significant effect on the height of sweet corn plants. As shown in Table 3, the highest sweet corn plant height was found in the Master Sweet variety $(171.67 \mathrm{~cm})$, whereas the lowest was found in the Talenta variety $(130.83 \mathrm{~cm})$.

The planting system did not affect the plant height, whereas varieties and harvest time had a significant effect. The best harvest time with the Legowo system was produced at 75 DAP $(162.8 \mathrm{~cm})$, whereas the regular system was at 65 DAP $(161 \mathrm{~cm})$.

3.3. Cob Length. Analysis of the data on the effect of the spacing system, corn variety, and harvest time on cob length showed that the effect of corn variety was statistically significant, whereas those of the others were not significant. The interactions between factors were not significant, indicating that the cob length was solely affected by variety. The Master Sweet variety had the longest cob $(28.08 \mathrm{~cm})$, whereas the Talenta variety had the shortest $(25.33 \mathrm{~cm})$ (Table 4).

3.4. Cob Diameter. The results of observations on the cob diameter of sweet corn showed that the effect of harvest time was significant. The longest diameter of the cob was found in the Bonanza variety $(6.18 \mathrm{~cm})$, whereas the shortest was found in the Talenta variety $(5.96 \mathrm{~cm})$. The harvest at the age of 75 DAP produced the largest cob diameters, both in control $(6.22 \mathrm{~cm})$ and in the Legowo system $(6.33 \mathrm{~cm})$. The effect of the spacing system and variety on the cob length was not significant. There was no significant interaction between the factors (Table 5).

3.5. Cob Weight. The results of the cob weight analysis showed that the weight of sweet corn cobs was influenced by variety and harvest time. The Bonanza variety produced the heaviest cob $(374.17 \mathrm{~g} / \mathrm{cob})$, whereas the Talenta variety produced the lightest $(310.83 \mathrm{~g} / \mathrm{cob})$. There was a significant effect of interaction between the planting system and harvest 
TABle 3: Plant heights of sweet corn $(\mathrm{cm})$ of different varieties and at different harvest times.

\begin{tabular}{|c|c|c|c|c|}
\hline \multirow{2}{*}{ Spacing and harvest time } & \multicolumn{3}{|c|}{ Variety } & \multirow{2}{*}{ Average } \\
\hline & $V 1$ & $V 2$ & $V 3$ & \\
\hline P0H1 & 186.33 & 121.67 & 175.00 & 161.00 \\
\hline $\mathrm{P} 0 \mathrm{H} 2$ & 165.00 & 125.00 & 156.67 & 148.89 \\
\hline P0H3 & 168.33 & 126.67 & 186.67 & 160.56 \\
\hline P1H1 & 156.81 & 133.33 & 178.33 & 156.16 \\
\hline $\mathrm{P} 1 \mathrm{H} 2$ & 165.00 & 136.67 & 166.67 & 156.11 \\
\hline P1H3 & 180.00 & 141.7 & 166.67 & 162.78 \\
\hline Average & $170.25 \mathrm{a}$ & $130.83 \mathrm{~b}$ & $171.67 \mathrm{a}$ & \\
\hline
\end{tabular}

Note. The numbers followed by different letters indicate the significant difference by LSD $(p<0.05)$.

TABLE 4: Cob length $(\mathrm{cm})$ of sweet corn plants of different varieties and at different harvest times.

\begin{tabular}{|c|c|c|c|c|}
\hline \multirow{2}{*}{ Spacing and harvest time } & \multicolumn{3}{|c|}{ Variety } & \multirow{2}{*}{ Average } \\
\hline & $V 1$ & $V 2$ & $V 3$ & \\
\hline $\mathrm{P} 0 \mathrm{H} 1$ & 27.67 & 27.67 & 29.00 & 28.11 \\
\hline $\mathrm{POH} 2$ & 26.90 & 22.00 & 27.00 & 25.30 \\
\hline $\mathrm{POH} 3$ & 25.33 & 25.33 & 29.67 & 26.78 \\
\hline$P 1 H 1$ & 26.73 & 27.33 & 27.50 & 27.19 \\
\hline$P 1 H 2$ & 26.90 & 23.83 & 26.33 & 25.69 \\
\hline$P 1 H 3$ & 26.17 & 25.8 & 29.00 & 27.00 \\
\hline Average & $26.62 \mathrm{ab}$ & $25.33 \mathrm{~b}$ & $28.08 \mathrm{a}$ & \\
\hline
\end{tabular}

Note. The numbers followed by different letters indicate the significant difference by LSD $(p<0.05)$.

Table 5: Cob diameters $(\mathrm{cm})$ of sweet corn plants of different varieties and at different harvest times.

\begin{tabular}{lcccc}
\hline Spacing and harvest time & \multicolumn{2}{c}{ Variety } & V3 & Average \\
\hline$P 0 H 1$ & $V 1$ & $V 2$ & 5.80 & 6.13 \\
$P 0 H 2$ & 6.16 & 5.63 & 6.16 & 6.10 \\
$P 0 H 3$ & 6.16 & 6.01 & 5.94 & 6.22 \\
$P 1 H 1$ & 6.37 & 6.14 & 6.10 & 5.95 \\
$P 1 H 2$ & 6.06 & 5.84 & 6.37 & 6.98 \\
$P 1 H 3$ & 5.92 & 5.92 & 6.08 \\
Average & 6.42 & 5.95 & 6.33 \\
\hline
\end{tabular}

time on the cob weight, where the results of the Legowo system at 75 DAP produced the highest cob weight $(372.22$ ton/ha), whereas a regular system with $65 \mathrm{DAP}$ produced the lowest (298.89 ton/ha) (Table 6).

3.6. Estimation Cob Weight per Hectare. The results of data analysis showed that all factors influenced the cob weight per hectare. As shown in Table 7, the highest estimation cob weight per hectare was significantly produced by the Bonanza variety (21.86 ton/ha), and the lowest was produced by the Talenta variety (18.17 ton/ha). There was a significant effect of interaction between the planting system and harvest time on the cob weight, in which the Legowo system at 75 DAP produced the highest cob weight (22.33 ton/ha), whereas a regular system with 65 DAP produced the lowest one (16.98 ton/ha).
3.7. Sugar Content. The results of the analysis of sugar content observed based on total dissolved sugar levels showed that the variety and harvest time were significantly affected by the sugar content. The highest corn sugar content was found in the Bonanza variety $\left(22.75^{\circ}\right.$ Brix $)$, whereas the lowest was found in the Talenta variety $\left(20.08^{\circ}\right.$ Brix). Harvesting at 65 DAP produced the highest sugar content $\left(22.83^{\circ}\right.$ Brix $)$, whereas the lowest was produced at 70 DAP (Table 8).

The growth and yield of sweet corn were influenced by the variety and the harvest time. The Master Sweet variety had the greatest plant height and cob length, whereas the Bonanza variety produced the greatest cob weight, cob weight per hectare, and sugar content. This difference indicated that the Master Sweet variety produced long and slim cob, whereas the Bonanza variety produced shorter but corpulent cob. This means that the Bonanza variety had 
TABLE 6: Cob weights (gram/cob) of sweet corn of different varieties and at different harvest times.

\begin{tabular}{|c|c|c|c|c|}
\hline \multirow{2}{*}{ Spacing and harvest time } & \multicolumn{3}{|c|}{ Variety } & \multirow{2}{*}{ Mean } \\
\hline & $V 1$ & $V 2$ & $V 3$ & \\
\hline$P 0 H 1$ & 346.67 & 256.67 & 293.33 & $298.89 \mathrm{c}$ \\
\hline $\mathrm{P} 0 \mathrm{H} 2$ & 351.67 & 313.33 & 343.33 & $336.11 b$ \\
\hline $\mathrm{POH} 3$ & 406.67 & 325.00 & 370.00 & $367.22 c$ \\
\hline$P 1 H 1$ & 400.00 & 306.67 & 336.67 & $325.80 \mathrm{bc}$ \\
\hline$P 1 H 2$ & 350.00 & 310.00 & 330.00 & $330.00 \mathrm{~b}$ \\
\hline$P 1 H 3$ & 390.00 & 353.3 & 373.33 & $372.22 \mathrm{~cd}$ \\
\hline Mean & $374.17 \mathrm{a}$ & $310.83 \mathrm{c}$ & $341.11 \mathrm{~b}$ & \\
\hline
\end{tabular}

Note. The numbers followed by different letters indicate the significant difference by LSD $(p<0.05)$.

TABle 7: Cob weights (ton/ha) of sweet corn of different varieties and at different harvest times.

\begin{tabular}{|c|c|c|c|c|}
\hline \multirow{2}{*}{ Spacing and harvest time } & \multicolumn{3}{|c|}{ Variety } & \multirow{2}{*}{ Mean } \\
\hline & $V 1$ & $V 2$ & $V 3$ & \\
\hline$P 0 H 1$ & 19.69 & 14.58 & 16.66 & $16.98 \mathrm{a}$ \\
\hline $\mathrm{POH} 2$ & 19.97 & 17.80 & 19.50 & $19.09 \mathrm{~b}$ \\
\hline $\mathrm{POH} 3$ & 23.10 & 18.46 & 21.02 & $20.86 \mathrm{c}$ \\
\hline$P 1 H 1$ & 24.00 & 18.40 & 20.20 & $20.87 \mathrm{bc}$ \\
\hline$P 1 H 2$ & 21.00 & 18.60 & 19.80 & $19.80 \mathrm{~b}$ \\
\hline $\mathrm{P} 1 \mathrm{H} 3$ & 23.40 & 21.20 & 22.40 & $22.33 \mathrm{~cd}$ \\
\hline Mean & $21.86 \mathrm{a}$ & $18.17 \mathrm{c}$ & $19.93 \mathrm{~b}$ & \\
\hline
\end{tabular}

Note. The numbers followed by different letters indicate the significant difference by LSD $(p<0.05)$.

TABLE 8: Sweet corn content $\left({ }^{\circ}\right.$ Brix) of different varieties and at different harvest times.

\begin{tabular}{lcccc}
\hline Harvest time (days) & \multicolumn{3}{c}{ Variety } & Average \\
\hline 65 & $V 1$ & $V 2$ & 23.17 & $22.83 \mathrm{a}$ \\
70 & 24.50 & 20.83 & 19.50 & $20.50 \mathrm{~b}$ \\
75 & 22.33 & 19.67 & 21.33 & $20.83 \mathrm{~b}$ \\
Average & 21.42 & 19.75 & $21.33 \mathrm{ab}$ & \\
\hline
\end{tabular}

Note. The numbers followed by different letters indicate the significant difference by LSD $(p<0.05)$.

greater cob lateral growth capability, so it has a longer diameter. Plant growth is an interaction between genetic and environmental factors [14]. Therefore, the difference in plant growth in the same environment, meaning that a greater genetic factor influences. Maize species pose different phenotypic character variations between one variety and other varieties. This result was consistent with the previous studies which reported high growth differences in corn plants from various genotypes tested [15-17].

The high production of Master Sweet and Bonanza varieties was supported by the size of the diameter of both, as well as on the cob length variable. A larger cob diameter and a longer cob allow the number of rows of seeds and allow the product produced per unit area to be heavier too. This is in line with another study that revealed the variable of fresh cob weight is positively correlated with the results obtained [18]. The difference in the production of the tested varieties is related to the genetic potential of each variety tested. Variety is one of the aspects to be considered for plant development because achieving high productivity is determined by genetic potential [19].
The high yield of the Bonanza varieties was also supported by better plant growth. This is consistent with the results obtained by Ahmad et al. [20], who concluded that maize yields positively and is significantly correlated with plant height, cob height, and yield components. High plant growth contributes to the possibility to leaf more [6]. With the presence of more leaves, capturing more solar energy is possible. This may accelerate the process of photosynthesis more rapidly and ultimately will produce plants with higher growth and production. The Legowo system produced higher chlorophyll content than did the conventional system when phosphor was added [21]. Our result is consistent with another study that shows that the Legowo system supports higher production than the conventional system [22]. By contrast, another study showed that the Bonanza variety has low to moderate yield and late-maturing when planting in the organic system [13].

The results of the analysis of sweet corn sugar levels showed that the sugar content is influenced by the variety and the harvest time. The highest sugar content was found in Bonanza and Master Sweet varieties, at 70 DAP. This is in 
line with the study by Haddadi [23], who proposed that the sugar and the harvest time are influenced by the variety used and added that sweet corn is harvested at the mature stage of milk. The differences in varieties and differences in harvest time affect the sugar content, in which the delay in harvest time will cause the concentration of water and sugar levels to decrease but the starch content to increase [24]. Conversely, the sweet corn harvest age is 60-70 DAP for planting in the lowlands [25].

\section{Conclusions}

Variety significantly influenced plant height, cob length, cob weight, cob weight per hectare, and sugar content. The Master Sweet variety had the greatest plant height and cob length, whereas the Bonanza variety produced the greatest cob weight, cob weight per hectare, and sugar content. Harvest time at 75 DAP produced the greatest harvest, while at 65 DAP produced the best sugar content. This study recommends the use of the Bonanza variety twin planted with the twin-row system to produce the greatest sweet corn harvest.

\section{Data Availability}

The authors state that all data generated or analyzed during this study are included in this article. The full data used to support the findings of this study are available from the corresponding author upon request.

\section{Conflicts of Interest}

The authors declare that there are no conflicts of interest regarding the publication of this paper.

\section{Acknowledgments}

This study was funded by the Universitas Muslim Indonesia.

\section{References}

[1] S. Erdal, M. Pamukcu, O. Savur, and M. Tezel, "Evaluation of developed standard sweet corn (Zea mays sacharata L.) hybrids for fresh yield, yield component and quality parameters," Turkish Journal of Field Crops, vol. 16, no. 2, pp. 153-156, 2011.

[2] P. H. A. D. Santos, M. G. Pereira, R. D. S. Trindade, K. S. D. Cunha, G. C. Entringer, and J. C. F. Vettorazzi, "Agronomic performance of super-sweet corn genotypes in the north of Rio de Janeiro," Crop Breeding and Applied Biotechnology, vol. 14, no. 1, pp. 8-14, 2014.

[3] R. N. Iriany, S. Sujiprihati, M. Syukur, J. Koswara, and M. Yunus, "Evaluasi daya gabung dan heterosis lima galur jagung manis (Zea may var. saccharata) hasil persilangan dialel," Jurnal Agronomi Indonesia, vol. 39, no. 2, pp. 103-111, 2011.

[4] The Indonesia Central Bureau of Statistics, Corn Production According to Province Data, The Indonesia Central Bureau of Statistics, Jakarta, Indonesia, 2015.

[5] J. H. H. Sonbai, D. Prajitno, and A. Syukur, "Pertumbuhan dan hasil jagung pada berbagai pemberian pupuk nitrogen di
Lahan kering regosol," Ilmu Pertanian, vol. 16, no. 1, pp. 77-89, 2013.

[6] St. Subaedah, S. Numba, and Saida, "Growth and yield performance of candidates hybrid maize genotypes for cobly harvest trait in dry land," Indonesian Journal of Agronomy, vol. 46, pp. 169-174, 2018.

[7] B. Kara and B. Atar, "Effects of mulch practices on fresh cob yield and yield components of sweet corn," Turkish Journal of Agriculture and Forestry, vol. 37, pp. 281-287, 2013.

[8] A. Saleem, "Response of maize cultivars to different NP-levels under irrigated condition in peshawar valley," Pakistan Journal of Biological Sciences, vol. 6, no. 14, pp. 1229-1231, 2003.

[9] D. Znidarcic, "Performance and characterization of five sweet corn cultivars as influenced by soil properties," Journal of Food Agriculture and Environment, vol. 10, no. 1, pp. 495-500, 2012.

[10] M. Szymanek, W. Tanaś, and F. H. Kassar, "Kernel carbohydrates concentration in sugary-1, sugary enhanced and shrunken sweet corn kernels," Agriculture and Agricultural Science Procedia, vol. 7, pp. 260-264, 2015.

[11] W. Abadi and A. N. Sugiharto, "Uji keunggulan beberapa calon varietas hibrida jagung manis (Zea mays L. var. saccharata)," Jurnal Produksi Tanaman, vol. 7, no. 5, pp. 939948, 2019.

[12] F. Azanza, B. P. Klein, and J. A. Juvik, "Sensory characterization of sweet corn lines differing in physical and chemical composition," Journal of Food Science, vol. 61, no. 1, pp. 253-257, 1996.

[13] M. Chozin, S. Sudjatmiko, Z. Muktamar, N. Setyowati, and F. Fahrurrozi, "Variability in growth and yield among sweet corn genotypes grown under organic crop management," IOP Conference Series: Earth and Environmental Science, vol. 347, p. 012007, 2019.

[14] F. P. Gardner, R. B. Pcobce, and R. L. Mitchell, Physiology of Crop Plants, p. 327p, Scientific Publishers, Singapore, 2010.

[15] S. Subaedah, A. Takdir, and H. Netty, "Evaluation of potential production of maize genotypes of cobly maturity in rainfed lowland," International Journal of Biological, Biomolecular, Agricultural, Food and Biotechnological Engineering, vol. 10, pp. 584-587, 2016.

[16] U. Zabih, H. Rahman, and N. Muhammad, "Evaluation of maize hybrids for maturity and related traits," Sarhad Journal of Agriculture, vol. 33, pp. 624-629, 2017.

[17] M. Khan, K. Khan, S. U. Afzal et al., "Seed yield performance of different maize (Zea Mays l.) genotypes under agro climate conditions of Haripur," International Journal of Environmental Sciences and Natural Resources, vol. 5, pp. 1-6, 2017.

[18] E. Ilker, "Correlation and path coefficient analyses in sweet corn," Turkish Journal of Field Crops, vol. 16, no. 2, pp. 105-107, 2011.

[19] M. J. Yusuf, G. Nabi, A. Basit, S. K. Husnain, and L. H. Akhtar, "Development of high yielding millet variety sargodha bajra2011 released for general cultivation in Punjab province of Pakistan," Pakistan Journal of Agricultural Science, vol. 49, pp. 299-305, 2012.

[20] Z. Ahmad, E. A. Waraich, T. Ahmad, R. Ahmad, and M. I. Awan, "Yield responses of maize as influenced by supplemental foliar applied phosphorus under drought stress," International Journal of Food and Allied Sciences, vol. 1, no. 2, pp. 45-55, 2015.

[21] P. G. Adinurani, S. Rahayu, L. S. Budi, S. Pambudi, and P. Soni, "Production potential of sweet corn (Zea mays Linn. var. Saccharata Sturt ) 'Bonanza' to different planting pattern 
and phosphorus sources," IOP Conference Series Earth and Environmental Science, vol. 293, Article ID 012032, 2019.

[22] T. Silangit, "Kajian sistem tanam jajar Legowo pada varietas jagung manis (Zea mays saccharata sturt," Thesis, Universitas Brawijaya, Malang, Indonesia, 2017.

[23] H. M. Hossein, "Investigation of characteristics and cultivation of sweet corn: a Review," International Journal of Farming and Allied Sciences, vol. 5, pp. 243-247, 2016.

[24] M. Syukur and A. Rifianto, Sweet Corn, Vol. 124, Penebar Swadaya, Jakarta, Indonesia, 2013.

[25] S. Surtinah, "Pengujian tiga varietas jagung manis (Zea mays saccharata) di Rumbai Kota Pekanbaru," Jurnal Ilmiah Pertanian, vol. 12, no. 1, pp. 37-43, 2015. 